DOROTA GUZOWSKA (Białystok)

\title{
PROBLEM HUSYCKI W POLSCE W PIERWSZEJ POŁOWIE XV WIEKU W ŚWIETLE NAJNOWSZYCH BADAŃ ${ }^{1}$
}

Problem husycki, nie bez pewnej racji, zaliczany jest do najbardziej przeinterpretowanych $\mathrm{w}$ polskiej historiografii. Podzielił tym samym los kilku innych, którym często przypisywano znaczenia, jakich nie posiadały. W historiografii polskiej odnajdziemy skrajnie odmienne poglądy na temat oddziaływania ruchu husyckiego na społeczeństwo polskie. Od tych wyrażających przekonanie o szerokim zasięgu społecznym husytyzmu w Polsce i jego doniosłej roli w kształtowaniu polityki i rozwoju świadomości narodowej, po te, reprezentujące stanowisko, że we wszystkich tych dziedzinach husytyzm zaistniał w Polsce jako cienki i efemeryczny nalot. Linia podziału na płaszczyźnie merytorycznej pokrywa się z dość łatwą do uchwycenia granicą chronologiczną. Otóż analiza opinii wydawanych przez historyków na temat wpływów herezji czeskiej w Polsce pokazuje wyraźnie, jak różnie interpretowano ten problem w literaturze okresu powojennego i tej powstałej w ciągu ostatnich 20 lat. Ukoronowaniem pracy obu pokolen historyków i jednocześnie najlepszym podsumowaniem każdego ze wspomnianych nurtów są dwie monografie husytyzmu w Polsce, wydane na przestrzeni 40 lat. W 1959 roku Ewa Maleczyńska ogłosiła swoją pracę Ruch husycki w Czechach i w Polsce, w której koncentruje się na społecznym obliczu husytyzmu i forsuje tezę o silnym oddziaływaniu na Polskę jego nurtu radykalnego ${ }^{2}$.

1 Artykuł ten jest skróconą i poprawioną wersją rozdziału pt.: Odgłosy husytyzmu $w$ Polsce $w$ świetle literatury mojej pracy magisterskiej zatytułowanej Międzynarodowe konteksty husytyzmu w świetle czeskiej, polskiej i stowackiej literatury $X X$ wieku, napisanej pod kierunkiem prof. dr. hab. Henryka Rucińskiego.

2 E. Maleczyńska, Ruch husycki w Czechach i w Polsce, Warszawa 1959. 
Autorka przedstawiła wizję ruchu husyckiego w Polsce jako walki klasowej zrewolucjonizowanego mieszczaństwa i chłopstwa przeciw duchowieństwu. Kilkadziesiąt lat później ukazała się praca Pawła Krasa Husyci w piętnastowiecznej Polsce ${ }^{3}$. Jest to obszerna synteza charakteru penetracji religijnych postulatów husytyzmu na terenie Polski i jego zasięgu społecznego. Autor podjął się trudu przewartościowania wizji polskiego husytyzmu. Odrzucił założenie nieuchronności walki klasowej, od nowa przeprowadził krytyczną analizę dostępnych źródeł i sformułował wnioski, nie próbując udowodnić rewolucyjnego charakteru wpływów husyckich w Polsce.

Obie wymienione prace są reprezentatywnymi przykładami obfitego, acz o przyczynkarskim raczej charakterze, piśmiennictwa poświęconego husytyzmowi w Polsce. Tak szerokiemu zainteresowaniu historyków tematyką husycką sprzyja stosunkowo rozległa baza źródłowa. Najchętniej wykorzystywanym informatorem pozostaje Jan Długosz, który husytyzmowi poświęca niemało miejsca na kartach swojej Historia Polonicae. Badacze mają również do dyspozycji wpisy do akt kościelnych, kościelne i świeckie źródła normatywne; ważną grupę stanowią źródła epistolarne ${ }^{4}$.

Mimo tej względnej łatwości w dostępie do źródeł w historiografii husytyzmu polskiego istnieje wiele wątków kontrowersyjnych, będących zwykle rezultatem wspomnianej na początku nadinterpretacji źródeł i dodawania wydarzeniom znaczeń, których nie posiadały. W niniejszym artykule chciałabym przedstawić aktualny stan wiedzy na temat polskiego husytyzmu i w jego świetle zaprezentować kilka szczegółowych problemów.

Husytyzm przenikał do Polski różnymi drogami niemal natychmiast po tym, jak pojawił się w Czechach. Ponieważ miejscem jego narodzin było środowisko uniwersyteckie, kontakty na poziomie wymiany naukowej były pierwszymi, które przyniosły do Polski wiedzę na temat reformy czeskiej. Wyjazdy polskích mistrzów i studentów nad Wełtawę dawały okazję zapo-

3 P. Kras, Husyci w piętnastowiecznej Polsce, Lublin 1998.

4 J. Długosz, Historia Polonicae libri XII, t. I-IV, ed. A. Przeździecki, w: Opera omnia, t. X-XIV, Kraków 1873-1879; Acta Capitulorum necnon iudiciorum ecclesiasticorum selecta, ed. B. Ulanowski, t. I-III, Kraków 1894-1918 (Monumenta Medii Aevi Historica Res Gestas Poloniae Illustrantia, t. XIII, XVI, XVIII); Bullarium Poloniae, ed. S. Kuraś, I. Sułkowska-Kuraś, t. IV-V, Lublin-Rzym 1992-1995; Statuty wieluńsko-kaliskie Mikołaja Traby z 1420 r., wyd. i opr. J. Fijałek, A. Vetulani, Kraków 1915-1951; Edykt wieluński, Volumina Legum, ed. J. Ohryzko, t. 1, Petersburg 1859; Codex epistolaris saeculi decimi quinti, ed. A. Sokołowski, J. Szujski, t. 1-III, Cracoviae 1876-1894 (Monumenta Medii Aevi Historica, t. II, XII, XIV); Codex epistolaris Vitoldi magni ducis Lithuaniae 1376-1430, ed. A. Prochaska, Kraków 1882 (Monumenta Medii Aevi Historica, t. VI). 
znania się z toczącą się w Pradze dyskusją. Wracali oni do Polski z odpisami kazań i przesiąknięci ideami odnowy Kościoła ${ }^{5}$. W 1413 r. przybył $\mathrm{z}$ misją do Polski Hieronim z Pragi. Jego wizyta była zaplanowaną podróżą agitacyjną, której cel stanowiło rozpowszechnianie postulatów ruchu husyckiego. Okazją do wzmożonego zainteresowania nauką Husa był też jego proces na soborze w Konstancji. Wywołał on liczne komentarze wśród polskich zwolenników i przeciwników mistrza Jana. Poza drogą wymiany naukowej odgłosy husytyzmu docierały do Polski za sprawą kontaktów handlowych. Rozwijały się one dzięki istnieniu dwóch szlaków tranzytowych wiodących $z$ południowych Niemiec przez Czechy do Lwowa oraz z Czech do Gdańska. Niewykluczone, że geograficzne rozmieszczenie skupisk utrakwistów na Kujawach wzdłuż szlaku handlowego jest dowodem również pozahandlowego charakteru kontaktów z Czechami udającymi się do Gdańska ${ }^{6}$.

Poszerzaniu informacji o husytyzmie, już w dobie rewolucji, sprzyjały polsko-czeskie kontakty dyplomatyczno-wojskowe. Potencjalnie szerokie możliwości zapoznania się z nauką husycką dawały wyprawy rycerstwa polskiego do Czech w 1422 i 1424 roku. Obecność wojsk husyckich w Polsce w 1433 roku nie jest jednoznacznie oceniana pod względem ich udziału w szerzeniu ideologii husyckiej na gruncie polskim. Przypuszcza się, że bezsensowne gwałty, okrucieństwo i bezwzględność husytów przysporzyły ich nauce w Polsce więcej wrogów niż zwolenników. Bogatym źródłem wiedzy o husytyzmie mogli być również Czesi osiedlający się w Polsce. W pierwszym dziesięcioleciu po wybuchu rewolucji byli to przeważnie - katoliccy uciekinierzy z Czech, których nie można posądzać o popularyzowanie w Polsce treści husyckich. Źródłem wiedzy na temat czeskich nowinek religijnych były też kazania antyhusyckie. Ze względu na ograniczony krąg czytelników książka nie stała się w Polsce szeroko stosowanym narzędziem propagandy religijnej.

Aktualny stan badań nad polskim husytyzmem pozwolił już w pewnym przybliżeniu ustalić jego zasadnicze treści. Naukowa, teologiczna strona nauczania Husa nie natrafiła w Polsce na podatny grunt. Marian Rechowicz w Dziejach teologii katolickiej w Polsce przekonuje, że generalnie husytyzm kojarzył się w Polsce $z$ wolnością od annat i dziesięcin, $z$ rozdzieleniem władzy duchowej i świeckiej, walką z niemczyzną, językiem narodowym w li-

5 P. Kras, op. cit., s. 35.

6 Ibidem, s. 53. 
turgii i Komunią pod obiema postaciami. I tylko te powierzchowne pojęcia stawały się częściami składowymi polskiego husytyzmu. Problematyka teologiczna dotycząca istoty Kościoła znana była tylko garstce ludzi wykształconych ${ }^{7}$. Nie badano w Polsce dogmatów husytyzmu, a i krytyka dogmatów katolickich dokonywana przez husy tów nie znalazła na polskim gruncie wielu słuchaczy ${ }^{8}$. Niemal we wszystkich opracowaniach dotyczących husytyzmu w Polsce podkreśla się, że hasłem, dzięki któremu zyskał on popularność, był postulat ubogiego Kościoła. Wśród innych, wymienianych w literaturze husytyzmu polskiego składników jego treści, pojawia się występowanie przeciwko nadużyciom służby Bożej dla zdobycia korzyści materialnych, uznawanie bezcelowości nabożeństw za zmarłych oraz odrzucanie kultu obrazów (bardzo sporadycznie). W polskim husytyzmie nie było postulatu swobody głoszenia Słowa Bożego ani nie interesowano się angażowaniem sądów państwowych w karanie grzechów publicznych. Zdaniem Mariana Rechowicza wynikało to $\mathrm{z}$ faktu, że polscy zwolennicy czeskiej herezji nie przejawiali ambicji apostolskich ani samokrytycznych ${ }^{9}$.

Jednym $z$ problemów, który w historiografii zajmującej się tematyką husytyzmu polskiego wzbudzał wiele kontrowersji, była sprawa zasięgu społecznego tego zjawiska. Zasadnicza dyskusja dotyczy kwestii, czy można mówić o internalizacji haseł husyckich przez społeczeństwo ziem polskich, czy raczej o krótkotrwałym i płytkim epizodzie. Jeśli chodzi o Wawel, należy jednoznacznie stwierdzić, że kwestia husycka, o ile tam istniała, traktowana była zasadniczo jako sprawa o wymiarze politycznym. W 1412 i 1413 r. król miał okazję zapoznać się bliżej z celami polskiego ruchu reformatorskiego. Stało się to za pośrednictwem listu od Husa, nawołującego króla do aktywnego włączenia się do dzieła odnowy Kościoła, oraz za sprawą wizyty w Krakowie mistrza Hieronima z Pragi. Również po 1420 r., gdy kwestia husycka zaistniała w Polsce jako problem polityczny, Władysław Jagiełło miał sposobność zapoznać się $\mathrm{z}$ jej treścią religijną, przyjmując posłów i patronując odbytym dwukrotnie dysputom (w 1421 i 1431 r.). Z chwilą, kiedy sobór w Konstancji uznał poglądy Husa za heretyckie, jakiekolwiek byłoby prywatne stanowisko

7 M. Rechowicz, Po zatozeniu Wydziatu Teologicznego w Krakowie, w: Dzieje teologii katolickiej w Polsce, t. I, Lublin 1975, s. 135.

8 T. Silnicki, Lata rozkwitu. A postolat powszechny. Próby reformy (1386-1506), w: Historia Kościoła w Polsce, red. B. Kumor, Z. Obertyński, t. I, Poznań-Warszawa 1974, s. 331; B. Zientara, Spoteczeństwo polskie w XII-XV wieku, w: I. Ihnatowicz, A. Mączak i in., Spoteczeństwo polskie od $X$ do $X X$ w., Warszawa 1988, s. 178.

9 M. Rechowicz, op.cit., s. 133. 
króla, jedyne co mógł w tej sytuacji uczynić, to wyrazić całkowite poparcie dla wyroku. Polityka Jagiełły wobec husytów w Czechach oraz postawa wobec zwolenników herezji na ziemiach polskich stała się z tą chwilą probierzem jego prawowierności i lojalności wobec europejskiej christianitas ${ }^{10}$. W literaturze i przyczynkach traktujących o odgłosach sprawy husyckiej na dworze polskim często pojawia się imię czwartej żony Władysława Jagiełły - Zofii Holszańskiej. Ewa Maleczyńska twierdzi, że podejmowane przez Zofię działania były nie tylko dowodem zmysłu politycznego, ale i silnych sympatii prohusyckich ${ }^{11}$. Dla potwierdzenia tego stanowiska przywołuje poparcie, jakiego udzieliła królowa konfederacji Spytka z Melsztyna. Współczesna historiografia nie posuwa się aż tak daleko w interpretacjach i na ogół uznaje się, że Zofia była po prostu zbyt zręcznym politykiem, by w rozgrywkach o koronę dla syna nie wykorzystać możliwości zwiększenia jego szans poprzez współpracę z przeciwnikami Oleśnickiego, nawet jeśli ci mieliby okazać się husytami ${ }^{12}$. Współczesna historiografia zaprzecza husyckiemu charakterowi zawiązanej przez Spytka konfederacji. Zasadniczo panuje zgodność, że to polityka była podstawowym motywem wydarzeń 1439 r. Roman Grodecki nazywa konfederację rozgrywką wewnątrzpolityczną między bezsilną opozycją a wszechwładnym Oleśnickim ${ }^{13}$. Kwestie religijne miały tu odgrywać rolę podrzędną, obie strony zaś traktować husytyzm wyłącznie jako argument w walce o władzę. Paweł Kras podejrzewa, że Spytko manifestował swe utrakwistyczne sympatie niejako „na złość" swojemu politycznemu rywalowi ${ }^{14}$. Jak dotąd ostateczny głos w sprawie konfederacji przyznaje się Annie Sochackiej. W 1973 r. na łamach "Rocznika Lubelskiego" próbowała ona rozstrzygnąć, czy była to rozgrywka polityczna, czy ruch ideologiczny. Konkluduje rozważania opinią, iż konfederacja była finałem walki stronnictwa Oleśnickiego i dworu Zofii o władzę w państwie. Spytko miał być jedynie tarczą dworu, wygodnym o tyle, że między nim a Oleśnickim istniał prywatny konflikt o zagarnięte dobra. Zdaniem Anny Sochackiej, udział dworu w całym przedsięwzięciu powinien być wystarczającym dowo-

10 P. Kras, op.cit., s. 231.

11 E. Maleczyńska, op.cit., s. 409.

$12 \mathrm{~W}$ najnowszej historiografii brakuje prac poświęconych biskupowi krakowskiemu Zbigniewowi Oleśnickiemu. Tymczasem jego ogromna rola w zwalczaniu husytyzmu w Polsce oraz jego pozycja na scenie politycznej, wzmocniona szczególnie po śmierci Władysława Jagiełły, zasługują na szczegółowa analizę.

13 R. Grodecki, Konfederacje w Polsce XV wieku, „Sprawozdania z Czynności i Posiedzeń PAU" 52 (1951), s. 884.

14 P. Kras, op.cit., s. 112. 
dem, by nie uznawać go za ruch o charakterze ideologicznym, husyckim. Dodatkowym argumentem, w przekonaniu autorki, był również brak zainteresowania konfederacja ze strony elit intelektualnych w Polsce. Co prawda były one niemal w całości nastawione antyhusycko, trudno byłoby zatem oczekiwać jakichś głosów poparcia. Ale że nie pojawiły się żadne, to zdaniem Anny Sochackiej sygnał, że traktowano konfederację wyłącznie jako rozgrywkę polityczną, a nie konfrontację ideologii wartą zainteresowania. Ostatecznie więc „konfederacja rysuje się jako ruch polityczny i trudno zgodzić się $\mathrm{z}$ próbami dostrzeżenia w niej wyrazu starcia się dwu ideologii. Była to typowa, rozgrywka polityczna między stronnictwami walczącymi o władzę w imię własnych, wcale nie ogólnospołecznych interesów" ${ }^{15}$. Niezależnie od faktycznej postawy Zofii wobec herezji, jak podkreśla Wacław Urban, najważniejszą konsekwencją całej sprawy, było objęcie przez królową mecenatu nad wielkim przedsięwzięciem ukończonym w 1455 roku - tłumaczeniem Biblii na język polski16. Czynnikiem, który mógł potencjalnie przyciągać polską szlachtę do husytyzmu, był trwający od dawna spór z duchowieństwem. W początku XV wieku wybuchł on z nową siłą. Na sejmach w Piotrkowie w latach 1406 i 1407 zawiązano konfederacje. Szlachta wystąpiła w obronie dziesięciny swobodnej, zażądała niestosowania klątwy kościelnej w sprawach dziesięcinnych i wystąpiła przeciw pozywaniu Polaków przed sąd papieski. Spory kościelno-szlacheckie trwały przez cały okres wpływów husytyzmu w Polsce. Naturalny konserwatyzm przypisywany szlachcie miał ją odstręczać od radykalnych treści społecznych napływających z Czech. Wbrew przekonaniu Ewy Maleczyńskiej najnowsza historiografia stoi na stanowisku, że taborycka wersja husytyzmu nie znalazła zrozumienia wśród polskiej szlachty, jedynie pewne elementy utrakwizmu przy jęte zostały jako atrakcyjna nowinka religijna. Brak ambicji intelektualnych sprawiał, że krytyka dogmatów znajdowała niewielu pilnych słuchaczy. Przypadki postaw wzorowanych na husyckich uznaje się generalnie za powierzchowne i efemeryczne, a rzeczywiste sympatie dla husyckiej doktryny religijnej, programu kościelnego i społecznego ocenia się jako niezwykle rzadkie w gronie szlachty polskiej. Szlacheckie nazwiska pojawiające się w źródłach w kontekście husyckim to Spytko z Melsztyna, Abraham ze Zbąszynia, Fryderyk Ostrogski, Piotr Polak z Lychwina, bracia, Piotr i Mikołaj Komorowscy czy Dobko Pu-

15 A. Sochacka, Konfederacja Spytka z Melsztyna z 1439 r. Rozprawa polityczna czy ruch ideologiczny?, „Rocznik Lubelski”, 16 (1973), s. 41-65.

16 W. Urban, Epizod reformacyjny, Kraków 1988, s. 13; T. Michałowska, Średniowiecze, Warszawa 1995, s. 569-574. 
chała $^{17}$. Jerzy Kłoczowski uważa, iż szlachecka postawa, w której zabrakło połączenia antyklerykalizmu z propozycjami husyckimi, sprawiła, że husytyzm stracił w Polsce jedyną szansę powodzenia. Brak szerokiego poparcia ze strony szlachty oznaczać musiał, jego zdaniem, nieuchronną klęskę husytyzmu na gruncie polskim ${ }^{18}$.

Motyw udziału tak zwanych mas ludowych w ruchu husyckim w Polsce, jak chyba żaden inny problem omawiany w literaturze polskiego husytyzmu, zasłużył sobie na zadziwiająco skrajne oceny w powojennej literaturze marksistowskiej i literaturze współczesnej. Podsumowując rezultaty swoich badań, Paweł Kras staje w wyraźnej opozycji wobec ustaleń historyków marksistowskich, stwierdzając, że nie istnieją podstawy źródłowe umożliwiające jednoznaczne rozstrzygnięcie sporu o faktyczne oddziaływanie husytyzmu na ludność polskich wsi i miast. Jego zdaniem nie sposób określić, na ile świadomy był udział wiernych utrakwistycznych w nabożeństwach sprawowanych w kościołach parafialnych. Podejrzewa, że jeśli nawet chłopi przyjmowali Komunię pod obiema postaciami, było to rezultatem postawy szlacheckiego patrona świątyni, a nie ich własnych przekonań i potrzeb. Fascynacja „nowinkami religijnymi” miała być - w opinii autora - bardzo powierzchowna i mijała wraz $\mathrm{z}$ aresztowaniem husyckiego kapłana i wycofaniem się szlachcica $z$ poparcia dla husytyzmu ${ }^{19}$.

Duże zainteresowanie wśród historyków wzbudziła kwestia wpływu husytyzmu na polskie duchowieństwo. Reakcje środowiska duchownego na herezję czeską były dwojakiego rodzaju. Postawa przytłaczającej większości tworzyła to, co było oficjalnym stanowiskiem Kościoła polskiego - negatywny stosunek wobec herezji czeskiej. Z drugiej strony pewna grupa kapłanów przejęła się autentycznie duchem ideologii husyckiej i stworzyła grono husyckich kaznodziejów. Nie było to środowisko liczne, choć należy przyznać, że to właśnie księża najczęściej pojawiają się w źródłach wśród osób podejrzanych o czeskie poglądy kacerskie lub je wyznających. W porównaniu $z$ oddźwiękiem, jaki zyskał husytyzm wśród innych grup społeczeństwa polskiego, reakcja polskiego duchowieństwa wydaje się najżywsza. Sprawił to nie tylko religijny charakter ruchu, czyniącego duchowieństwo niejako au-

17 O trzech ostatnich spośród wymienionych osób twierdzi się, że byli zwykłymi łotrami, szukającymi okazji do zagrabienia dóbr i majątku kościelnego (patrz: biogramy w Polskim stowniku biograficznym, t. VII, Wrocław 1948-1958; t. XIII, Wrocław 1967-1968).

18 J. Kłoczowski, Europa stowiańska w XIV-XVw., Warszawa 1984, s. 235.

19 P. Kras, op.cit., s. 162. 
tomatycznie środowiskiem najbardziej zainteresowanym. Nasze przekonanie o największym oddźwięku husytyzmu wśród księży może wynikać również z tego, że właśnie oni, jako osoby kształtujące religijne postawy parafian, byli najpilniej kontrolowani. Ściślejsza kontrola oznacza dla współczesnych historyków, że właśnie księżowskie nazwiska znajdą najczęściej w dokumentach w kontekście husyckim.

Grupa, w której historycy również poszukiwali odgłosów husytyzmu, były polskie elity intelektualne. Zagadnienie to, dość obszernie omawiane w polskiej historiografii, jest o tyle ciekawe, że dotyczy środowiska, obok duchowieństwa, najbardziej chyba podatnego na wpływy nowych koncepcji i doktryn. Z drugiej strony, postawa uniwersyteckich elit umysłowych była bardzo istotna tak dla ludzi tamtej epoki, jak i dla dzisiejszych historyków, próbu jących tę epokę zrozumieć. Właśnie na początku XV wieku w Europie autory tet uniwersytetów osiąga punkt kulminacy jny. Stawia się go na równi, a jak pokazał sobór w Konstancji, nawet wyżej od autorytetu papieskiego. Również w Polsce opinie mistrzów uczelni krakowskiej w wielu dziedzinach wspomagały politykę państwa i kreowały światopogląd jej wykonawców. Nie ma zasadniczo kontrowersji wśród historyków na temat generalnej postawy polskich kręgów uniwersyteckich wobec husytyzmu. Panuje zgodna opinia, że Uniwersytet Jagielloński opowiedział się przeciwko drodze zaproponowanej przez Jana Husa i nie otworzył swoich podwojów nauce husyckiej. Na płaszczyźnie filozoficznej przeszkodą w przepływie myśli i pozytywnym odbiorze doktryny Husa były różnice preferowanych kierunków. Uniwersytet praski ewoluowal już w stronę realizmu, natomiast Kraków pozostawał w kręgu nominalizmu. Z punktu widzenia intelektualistów ta niezgodność wyznawanych kierunków filozoficznych była istotnym czynnikiem zamykającym husytyzm̧owi dostęp na polski uniwersytet. Istniała również płaszczyzna finansowa. Prebendy kościelne, z których utrzymywali się profesorowie, zależne były od zatwierdzeń papieskich. W takich okolicznościach nie można było oczywiście myśleć o poparciu husytyzmu uznawanego oficjalnie za herezję i sprzeciwić się w ten sposób papieżowi. Jeszcze innym czynnikiem zniechęcającym środowisko uniwersyteckie w Polsce do husytyzmu było zaangażowanie uczelni w tworzenie filozoficzno-naukowego tła dla politycznego konfliktu Polski z Zakonem. Czynnik ten zadziałać miał na dwóch płaszczyznach. Po pierwsze, walka $z$ katolickim zakonem wymagała bardzo ostrożnego postępowania wobec kurii rzymskiej. Dla dobra interesów politycznych Polski niewskazane było zrywanie stosunków z papiestwem poprzez opowiedzenie się za herezją. Po drugie, problematyka konfliktu na północnej granicy tak dalece pochłonęła umysły i energię profesorów krakowskich, że 
nawet w czasie najgorętszych dysput husyckich w Pradze w Krakowie na pierwszym planie pozostawał motyw krzyżacki ${ }^{20}$. Bardzo ciekawe refleksje snuje Jerzy Kłoczowski, przyznając, że problem husycki poróżnił uniwersytety czeski i polski i sprawił, że poszły one odmiennymi drogami. Zauważa jednak, że mimo krytycznego stosunku polskiej elity intelektualnej do herezji czeskiej nie można mówić, iż wykazywała ona w tej kwestii jakiekolwiek ślady fanatyzmu. Panowało raczej w Krakowie zainteresowanie innymi propozycjami i poszanowanie cudzych poglądów ${ }^{21}$. Mimo generalnie niechętnego nastawienia, z jakim spotkał się husytyzm na Uniwersytecie Jagiellońskim, znalazły się i w tym środowisku osoby sympatyzujące $z$ programem reformy husyckiej. Najbardziej znanym przykładem jest Jędrzej Gałka z Dobczyna - wykładowca uniwersytecki i kanonik kapituły św. Floriana, autor jednego z najwcześniejszych zabytków języka polskiego - Pieśni o Wiklefie.

Skala odgłosów husytyzmu w społeczeństwie polskim nie była na tyle duża, by istniało zagrożenie powtórki czeskiego scenariusza. Przez wzgląd jednak na bliskie sąsiedztwo z Czechami i możliwość szybkiego przenikania stamtąd poglądów heretyckich władze kościelne i świeckie podjęły kroki, których celem było zapobieżenie potencjalnemu niebezpieczeństwu. Husytyzm był dla polskiego Kościoła pierwszą poważną próbą starcia z prądami heterodoksy jnymi. Trybunał inkwizycy jny dla ziem polskich istniał już wprawdzie od początku XIV wieku, gdy do Królestwa Polskiego napłynęła fala biczowników, ale historycy zgodnie uznają, że do XV wieku Polskę omijały większe perturbacje związane $z$ ruchami heretyckimi. Decyzja soboru w Konstancji o potępieniu nauki Jana Husa zobowiązywała Kościół w Polsce do podjęcia działań przeciw polskim zwolennikom husytyzmu. W 1420 roku w Wieluniu i Kaliszu obradował synod zwołany przez arcybiskupa gnieźnieńskiego Mikołaja Trąbę. Wśród wielu dyskutowanych zagadnień znalazły się również te dotyczące zwalczania husytyzmu w Polsce. Ich ślad odnajdziemy w dwóch artykułach Statutów wieluńsko-kaliskich zatytułowanych De haereticis i Remedia contra hereticos ${ }^{22}$. W artykułach tych zdefiniowano poglądy, które należy uznawać za heretyckie, oraz ustalono metody poszukiwania, ścigania, sądzenia i karania heretyków. Jak twierdzi ostatnio Paweł Kras, regulacje synodu miały przede wszystkim charakter profilaktyczny, a ich zadaniem

20 J. Garbacik, A. Strzelecka, Uniwersytet Jagielloniski wobec problemów husyckich w XV wieku, w: „Acta Universitatis Carolinae. Historia”, 5 (1964), s. 50.

21 J. Kłoczowski, op.cit., s. 228 i n.

22 Statuty wieluńsko-kaliskie, s. 94-96. 
było zapobieganie przenikaniu i rozprzestrzenianiu się nowinek husyckich $\mathrm{w}$ Polsce, a nie walka $\mathrm{z}$ realnie istniejącym i szeroko rozpowszechnionym ruchem heretyckim ${ }^{23}$. Stworzyły one jednak prawne podstawy walki $z$ husytyzmem, które stały się wzorem dla późniejszych działań władz kościelnych. W pierwszej połowie XV wieku opracowano szereg szczegółowych rozporządzeń dotyczących zwalczania husytyzmu w poszczególnych diecezjach. W 1420 r. sporządzono również instrukcję wizytacyjną, tzw. Ordo visitationis, na podstawie której biskupi mieli identyfikować heretyków ${ }^{24}$. Jak uważa Jadwiga Krzyżaniakowa, antyhusyckie przepisy prawodawstwa kościelnego nie byłyby jednak efektywnym zabezpieczeniem przed herezją, gdyby nie szeroko zakrojona działalność duszpasterska ${ }^{25}$. Problem kształtowania wizerunku heretyka na potrzeby propagandy kościelnej zyskał w ostatnich latach doskonałych badaczy w osobach Stanisława Byliny i Edwarda Potkowskiego. Edward Potkowski zauważa, że treścią polskiej polemiki antyheretyckiej, zarówno tej traktatowej, jak i popularnej, rzadko były kwestie dotyczące eklezjologii czy Eucharystii - podstawowe dla husytyzmu. Przeciwnie, kaznodziejstwo operuje obrazami i pojęciami dość dalekimi od teologii, za to silnie oddziałującymi na wyobraźnię. W opinii autora wynikało to $z$ faktu, że celem nie była dyskusja $z$ herezją husycką, ale jej zwalczanie ${ }^{26}$. Dlatego kaznodziejstwo nie poszukuje odpowiedzi na stawiane przez husytów postulaty, ale modeluje ich wizerunek tak, aby zniechęcić do osób, jak i ich poglądów. Widzi się więc w heretykach „synów szatana”, inspirowanych i kierowanych przez niego, choć, jak twierdzi Stanisław Bylina, taka profetyczna wizja heretyków jako sług Antychrysta, siejących spustoszenie w przeddzień końca świata, nie była w Polsce nadużywana ${ }^{27}$. Bardzo powszechne było natomiast odwoływanie się do wartości, o której František Šmahel pisze, że była najcenniejszą wartością człowieka średniowiecznego. Ma on na myśli poczucie przynależności do wspólnoty. Świadomość ta wyznaczała miejsce jednostce, w znacznej mierze determinowała jej postawy. Człowiek wyrwany ze wspól-

23 P. Kras, op. cit., s. 215.

24 "Modus inqurendi super statu ecclesiae generalis" $z$ pierwszej potowy XV stulecia, wyd. i opr. B. Ulanowski, w: Scriptores rerum Polonicarum, t. XIII, Kraków 1889, s. $199-200$.

25 J. Krzyżaniakowa, Koncyliaryści, heretycy, schizmatycy w państwie pierwszych Jagiellonów, Kraków 1989, s. 64.

26 E. Potkowski, Stereotyp heretyka-innowiercy w piśmiennictwie kaznodziejskim, $\mathrm{w}$ : Kultura elitarna i kultura masowa w Polsce późnego średniowiecza, red. B. Geremek, Wrocław 1978, s. 133.

27 S. Bylina, Ruchy heretyckie w średniowieczu. Studia, Wrocław 1991, s. 134. 
noty nie był w stanie samodzielnie funkcjonować. Oddzielenie się na własne życzenie, albo, co gorsza, próby podważania ustalonego porządku były najcięższymi zbrodniami ${ }^{28}$. Wykorzystując ten motyw, kaznodziejstwo antyhusyckie w Polsce ustala stereotyp heretyka jako osoby łamiącej normy etyki i obyczajowości wspólnej, burzącej porządek publiczny, utrudniającej tym samym zapobieganie przestępstwom i zbrodniom ${ }^{29}$. Często przedstawiano husytę jako kogoś spoza kręgu lokalnej społeczności, kto przychodzi i swą przewrotną nauką zwodzi ludzi prostych i niewykształconych, wyobcowując ich ze społeczeństwa ${ }^{30}$. Wiązaniu przyjęcia husytyzmu $z$ perspektywą przerażającej izolacji służyło coroczne odczytywanie w czasie Wielkiego Postu wykazu kategorii grzeszników, nie mogących przystąpić do Komunii Wielkanocnej bez specjalnej absolucji biskupa. Zdaniem Stanisława Byliny miało to utworzyć w świadomości słuchających wyobrażenie heretyka jako wielkiego grzesznika, wyłączonego poza obręb wspólnoty parafialnej, dla której coroczna Eucharystia Wielkanocna była ważnym znakiem jedności. Podobną funkcję miało spełniać również stałe przypominanie o zakazie kościelnego pogrzebu dla ekskomunikowanych ${ }^{31}$. Nie wspominają autorzy o dwóch dodatkowych czynnikach, które sprawiły, że przy jęcie husytyzmu oznaczało katastrofę. Powszechna w średniowieczu obawa przed wiecznym potępieniem powstrzymywała przed poparciem herezji, wyklętej przez Kościół. Poczucie wspólnoty, o którym była mowa wyżej, miało również swój wymiar mistyczny. Wiązało się z przekonaniem, że grzech, odszczepieństwo jednego jej członka, sprowadza gniew Boży na pozostałych. Dlatego w trosce o własne życie wieczne starano się nie dopuszczać do upowszechnienia się kacerstwa. Wykluczano husytów-heretyków z grona lokalnej społeczności, przypisując im cechy, które zagrażać miały jej zdrowiu i stabilności. Znalazły się wśród nich zarozumialstwo, odrażająca brzydota, tchórzliwość, pycha, obłuda i pozorna pobożność. Typowo „husyckie” były - pogarda dla kultu świętych i ich wizerunków, świętokradcza postawa wobec Komunii. Pod wpływem wieści o wojnach husyckich wykrystalizował się obraz heretyka stosującego gwałt i przemoc ${ }^{32}$. Postrzeganie działalności husyckich kaznodziejów jako podstępnego wykorzystywania nieświadomej zagrożenia ludności prowadziło do utożsamienia heretyka $z$ wilkiem polującym z zaskoczenia $\mathrm{i}$ w ciemności.

\footnotetext{
28 F. Smahel, Husitská revoluce, Praha 1993, t. IV, s. 29.

29 E. Potkowski, op.cit., s. 130.

30 S. Bylina, op.cit., s. 108.

31 Ibidem, s. 126.

32 E. Potkowski, op.cit., s. 128, 134; S. Bylina, op.cit., s. 141.
} 
Rezultat był taki, że - jak uważa Edward Potkowski - utrwaliło się przekonanie, iż husyty - kacerza, który przejmuje cechy wilka, należy unikać jak wilka i tępić jak wilka ${ }^{33}$.

W 1430 r. Polską wstrząsnęła wiadomość o napadzie na klasztor jasnogórski. Obrabowany został skarbiec, zniszczony obraz Czarnej Madonny, wywiezione wota, szaty i sprzęt liturgiczny. Winą za zbrodnię natychmiast obarczono husytów czeskich stacjonujących na Śląsku ${ }^{34}$. Propaganda antyheretycka w Polsce dostała niechcący potężną broń do ręki. Profanacja świętego miejsca polskiego chrześcijaństwa była czynem, który skazywał sprawców na powszechne potępienie, korzystnie było więc przypisać go obrazoburczej furii heretyków. O celowym zniszczeniu cudownego obrazu był przekonany sam Jan Długosz, chociaż generalnie nie miał wątpliwości, że faktycznym celem ataku na Jasną Górę było zagrabienie znajdujących się tam skarbów ${ }^{35}$. Do takich wniosków dochodzi również współczesna historiografia. Posługując się wynikami ekspertyz obrazu, podważa ona nawet i relację dziejopisarza o pocięciu wizerunku Madonny mieczami. Z badań wynika bowiem, że ślady na twarzy Maryi powstały podczas zrywania ozdób, a drewno w miejscach „cięć" jest całe ${ }^{36}$. Oznaczałoby to, że nie zniszczenie cudownego obrazu, ale zwykła chęć zdobycia łupów była celem ataku. Paweł Kras stwierdza, że wydarzenie to nosiło znamiona działań typowych dla najemników pozostających na służbie wojsk husyckich, ży jących ze zdobyczy wojennych. Nazwiska wymienionych przez Długosza sprawców, wśród których znaleźli się książę Fryderyk Ostrogski, Jan Kuropatwa i Jakub Nadobny, sugerują - zdaniem Pawła Krasa - że rabusiami mogła być po prostu polska szlachta, wykorzystująca sąsiedztwo załóg husyckich i podszywająca się pod nie ${ }^{37}$.

Antyheretyckiemu prawodawstwu kościelnemu towarzyszyły kroki podejmowane przez władze świeckie. Pierwszym oficjalnym przedsięwzięciem państwowym była aprobata postanowień soboru w sprawie Husa. Władysław Jagiełło w liście do ojców soboru obiecał podporządkować się decyzjom podjętym w Konstancji, a tym samym udzielił wsparcia antyhusyc-

33 Ibidem, s. 129.

34 J. Długosz, op.cit., t. IV, s. 399.

35 Ibidem, s. 399-400.

36 Bilnik, Napad „husytów” na Jasna Górę. Fakty-konteksty-legenda, „Studia Claromontana", 15 (1995), s. 304-306.

37 P. Kras, op. cit., s. 195. 
kim działaniom Kościoła w Polsce ${ }^{38}$. Do 1423 r. Jagiełło powstrzymywał się jednak przed zdecydowanymi krokami przeciw polskim husytom. Kontakty polityczne z Czechami w latach 1420-1422, skoncentrowane wokół planów oddania korony czeskiej Jagielle, a potem Witoldowi, opóźniły realizację zobowiązań wobec soboru. W 1423 r. polski monarcha zawarł z Zygmuntem Luksemburczykiem porozumienie w Kieżmarku. Zgodnie $z$ jego warunkami z Czech odwołany został namiestnik Witolda - książę Zygmunt Korybutowicz, a strona polska zobowiązała się nie udzielać jakiegokolwiek poparcia husytom. W zamian za to Luksemburczyk rozpatrzyć miał ponownie wyrok wrocławski (z 1420 r.) w sporze polsko-krzyżackim i wycofać się z poparcia dla Zakonu ${ }^{39}$. Dla polskich zwolenników husytyzmu najpoważniejszym skutkiem zwrotu w polityce państwa wobec Czech było uznanie ich poglądów za crimen laesae maiestatis. W $1424 \mathrm{r}$. w Wieluniu ogłoszony został edykt regulujący udział władz państwowych w walce $z$ herezją czeską. Pod groźbą infamii, banicji, utraty przywilejów oraz dóbr zakazywano wszelkich kontaktów z Czechami ${ }^{40}$. Benedykt Zientara zauważa, że postanowienia edyktu, uderzające $w$ gwarancje nietykalności osobistej i nienaruszalności mienia, mogły być odebrane jako atak na wolności szlacheckie i dlatego miały prawo być przyjmowane niechętnie ${ }^{41}$. Tymczasem Paweł Kras wskazuje na konfederację szlachecką w 1424 r., która potwierdziła edykt wieluński i wyraziła poparcie dla kar przewidzianych w nim za herezję. Jego zdaniem postanowienia konfederacji dowodzą, że edykt wieluński nie był wyłącznie deklaracją polityczną, wydaną na użytek zagranicznych dworów, ale przemyślanym aktem prawnym określającym rzeczywistą politykę religijną w państwie ${ }^{42}$. Państwowe uchwały antyhusyckie podejmowane były jeszcze dwukrotnie. Kwestią dyskusyjną pozostaje, czy było to dowodem determinacji władz w zwalczaniu herezji, czy dowodziło nieskuteczności każdego poprzedniego rozporządzenia. Nie jest pozbawione podstaw również i stanowisko przypisujące inicjatorom uchwał antyhusyckich wyłącznie pobudki polityczne. I tak antyheretyckie postanowienia zjazdu jedlneńskiego w 1430 r. miały być inicjatywą grupy możnowładców małopolskich, którzy w ten sposób uderzali w opozycję wobec obozu Oleśnickiego, opowiadającą się za ścisłym

38 Magnum Oecumenium Concilium Constantiense, t. IV, ed. H. Hardt, Frankfurt-Leipzig 1697-1700, 868.

39 Codex diplomaticus Lithuaniae, ed. E. Raczyński, Wrocław 1849, s. 300-303.

40 Edykt wieluński, Volumina Legum, t. I, 38.

41 B.Zientara, op.cit., s. 154.

42 P. Kras, op.cit., s. 154. 
sojuszem z Czechami43. Konfederacja korcżńska z 1438 r. natomiast była skierowana przeciwko grupie szlachty forsującej pomysł kandydatury polskiego królewicza Kazimierza Jagiellończyka na tron czeski ${ }^{44}$. Ta ostatnia kwestia przypomina, że problem husycki był nie tylko sprawą wewnętrzną państwa polskiego, ale istniał również na płaszczyźnie stosunków międzynarodowych.

Kwestia nawet jeszcze nie husycka, ale husowa, zaistniała dla Polski w kontekście międzynarodowym po raz pierwszy w okresie soboru w Konstancji, gdy ważyły się losy czeskiego reformatora. Świeccy posłowie złożyli wówczas protest, ujmując się za Husem, ale twierdzi się, że uczynili to wyłącznie przez wzgląd na poniżające warunki, w jakich znalazł się głośny profesor, a nie przez wzgląd na jego naukę ${ }^{45}$. Sprawa Husa w pojęciu polskiej delegacji przynależała do nieporównywalnie niższej kategorii ważności niż sprawa sporu z Zakonem. Obrona heretyka nie mieściła się w polskiej racji stanu, która w owej chwili wymagała raczej utrzymania poprawnych stosunków tak z soborem, jak i z Zygmuntem Luksemburczykiem ${ }^{46}$. Otwarte opowiedzenie się Polski w obronie Husa było nierealne, bo groziło zaprzepaszczeniem rezultatów pracy dyplomacji polskiej, odpierającej od lat rozpowszechniane przez Zakon oskarżenia Jagiełły o działanie na szkodę duchowieństwa ${ }^{47}$.

O właściwej kwestii husyckiej w polskiej polityce zagranicznej można mówić od 1421 r., kiedy po raz pierwszy husyci zwrócili się do Władysława Jagiełły z prośbą o przyjęcie korony Królestwa Czeskiego. Stało się to zaraz po tym, jak Zygmunt Luksemburczyk wydał we Wrocławiu niekorzystny dla Polski wyrok w sprawie sporu polsko-krzyżackiego. Husyci zdawali sobie sprawę z tego, że rozczarowanie Jagiełły i Witolda wyrokiem wrocławskim należy wykorzystać przeciw Luksemburczykowi. Z drugiej strony i dla Polski propozýcja czeska i okazja wmieszania się w wewnętrzne sprawy Luksemburczyka okazała się kuszącą perspektywą rozgrywki politycznej, której celem było uniemożliwienie Zygmuntowi czynnego wystąpienia po stronie Zakonu w planowanej przez Polskę rewizji wyroku. Zakłada się dziś, że Jagiełło wykluczał od początku unię Polski z Czechami jako sprzeczną

43 Ibidem, s. 238.

44 Ibidem, s. 239.

45 A. Prochaska, Sobór $w$ Konstancji, wyd. II, Kraków 1996, s. 22, 111.

46 T. Silnicki, Sobory powszechne a Polska, Warszawa 1962, s. 78.

47 A. Sochacka, Husyci w Czechach i w Polsce, w: Od Zawiszy do Tarnowskiego: szkice $z$ epoki jagiellońskiej, red. M. Podgórski, A. Witusik, Lublin 1987, s. 55. 
z prawem, bezpodstawną, niebezpieczną pod względem religijnym i politycznym i w rezultacie - nierealistyczną ${ }^{48}$. Całe przedsięwzięcie miało być tylko manewrem politycznym, czego najlepszym dowodem był fakt, że równolegle do serdecznych rozmów z posłami czeskimi odbywały się rozmowy z Luksemburczykiem w Tyrnawie (Trnava). Poinformowano tam Zygmunta, że Polska odstąpi od starań o koronę czeską natychmiast, gdy zobowiąże się on uśmierzyć Krzyżaków, a jako rękojmię wypełnienia umowy przekaże Polsce Śląsk. Pertraktacje nie powiodły się, ale Jagiełło korony czeskiej i tak nie przyjął. Zgodził się na nią książę Witold, wysłał do Czech jako swego pełnomocnika księcia Zygmunta Korybutowicza, ale i ta decyzja stanowiła jeszcze jeden element strategii politycznej monarchii polsko-litewskiej, obliczony na wywarcie skutecznego nacisku na króla rzymskiego. Wkrótce pokój melneński i zrealizowanie planów względem Żmudzi sprawiły, że sprawa husycka przestała odgrywać rolę asa $\mathrm{w}$ rękawie w rozgrywce $\mathrm{z}$ Luksemburczykiem i zrezygnowano z dalszego w nią zaangażowania, czego efektem była umowa zawarta z Zygmuntem w Kieżmarku.

Słabo zbadanym jak dotąd fragmentem stosunków polsko-czeskich jest okres od roku 1423 aż po rok 1431, kiedy podjęto ponownie oficjalne kontakty dyplomatyczne. Wydaje się, że aktywność dworu w staraniach o uznanie dziedziczności tronu tak szczelnie wypełniła ten okres, że można mówić, iż mało zostało już tam miejsca na intrygi międzynarodowe. Chyba zresztą i Czesi mniej byli zainteresowani ścisłym związkiem z Koroną Polska, skoro nie ponawiali próśb, a i Korybutowicza, który w 1424 r. ponownie udał się do Czech, nie tolerowali zbyt długo.

Wydarzeniem, przy okazji którego porusza się w literaturze problem czynnika husyckiego w polskiej dyplomacji, są zabiegi wokół korony dla wielkiego księcia Witolda. Pomysł korony dla Witolda miał trzech ojców. Dla samego księcia była to okazja zaspokojenia ambicji. Jagiełło upatrywał tu środek szantażu wobec szlachty polskiej, która chcąc utrzymać unię, zmuszona byłaby wybrać królem jednego z synów Władysława. Trzecim zainteresowanym realizacja planu koronacji Witolda był Zygmunt Luksemburczyk. I tu właśnie historycy wskazują na wplatający się wątek husycki. Oskar Halecki zauważa, że król rzymski doskonale zdawał sobie sprawę z roli, jaką w monarchii polsko-litewskiej odgrywał Witold, i dlatego właśnie zależało mu na rozbiciu tej solidarności władców. Solidarność ta była bowiem dla

$48 \mathrm{Cz}$. S. Bartnik, Rzym a stosunki polsko-czeskie za Władystawa Jagietty (13861434), Lublin 1993, s. 136. 
Luksemburczyka głównym zagrożeniem w sprawie husyckiej ${ }^{49}$. Wątek ten rozwija w swojej pracy Czesław S. Bartnik. Wyjaśnia, że chodziło o zabiegi, jakie czynił Marcin V w celu nakłonienia Jagiełły i Witolda do wspólnego rozwiązania sprawy husyckiej. Autor przypuszcza, że ze strony papieża była to również gra polityczna, obliczona na pobudzenie aktywności Zygmunta, który wykręcał się od poprowadzenia kolejnej krucjaty. Tak czy inaczej, szerokie uprawnienia, jakich udzielił Jagielle papież w bulli z 1428 r., rzeczywiście zaniepokoiły Zygmunta. Obawiał się, że odsuną go one od decyzji w sprawach Czech, nie mówiąc o utracie autorytetu w Europie ${ }^{50}$. Nie miał zatem innego wyboru, jak skierować energię Jagiełły w inną stronę. Wtedy właśnie, na zjeździe w Łucku, przypomniał o podnoszonych już dawniej planach ukoronowania Witolda. Jak wiadomo, przedsięwzięcie nie powiodło się, zamiary pokrzyżowała śmierć Witolda. Nie zamknęło to jednak husyckiego rozdziału w podtekstach polskiej polityki zagranicznej. W $1431 \mathrm{r}$. Zygmunt Luksemburczyk zmusił Marcina V do zwołania soboru i oddania w jego ręce sprawy husyckiej. Papież, obawiając się, że problem wymknie mu się spod kontroli, podjął pertraktac je z Jagiełłą. Król miał w jego imieniu rozpocząć rozmowy z husytami. W tym też kontekście odbyła się w $1431 \mathrm{r}$. w Krakowie dysputa religijna oraz wyruszyło poselstwo polskie do Pragi. Konflikt polsko-litewski, który wybuchł kilka tygodni później, doczekał się rozinaitych interpretacji. W większości $z$ nich pojawiły się wątki husyckie. Jadwiga Krzyżaniakowa i Jerzy Ochmański sugerują, że to zaniepokojony Zygmunt rozpoczął starania, by uniemożliwić Jagielle interwencję w Czechach. Środkiem miało być zainspirowanie Świdrygiełły do wydania wojny Polsce ${ }^{51}$. Zdaniem autorów również inicjatywa zamachu na Świdrygiełłę latem 1432 r. wyszła $z$ kół zainteresowanych zerwaniem polsko-husyckiego przymierza zawartego w Pabianicach w lipcu 1432 r. Przymierze to było konieczne, ponieważ nie udało się zmusić Świdrygiełły do zerwania sojuszu z Zakonem, do wojny z którym szykowała się właśnie Polska. Wyeliminowanie księcia z gry miało uczynić umowę z heretykami zbędną ${ }^{52}$. Wygnany z Wilna Świdrygiełło wraca jednak po swoje i jesienią 1432 r. rozpętuje wojnę domową. W tej sytuacji wyprawa wojsk wspomaganych przez oddziały sierotek pod wodzą Jana Capka z Sanu spełniać mogła rolę działań

49 O. Halecki, Dzieje Unii Jagiellońskiej, t. I, Kraków 1919, s. 241.

50 Cz. S. Bartnik, op.cit., s. 116.

51 J. Krzyżaniakowa, J. Ochmański, Wtadystaw II Jagietło, Wrocław 1990, s. 295.

52 Ibidem, s. 297. 
prewencyjnych, wyprzedzających realizację zobowiązań istniejących między Świdrygiełłą a Krzyżakami. Problemem, który wzbudził szerokie kontrowersje, jest pytanie, czy wojska husyckie kroczące w 1432 r. nad Bałtyk, były siłami sojuszniczymi czy najemnymi. Teorii o najemnym charakterze wojsk sierotek gwałtownie sprzeciwił się J. Macek. Jego zdaniem, żołdy i dostawy obuwia, sukna i broni zapewniane przez Polskę oddziałom husytów były wyłącznie dowodem tego, że „umowa o przyjaźni” została wykonana i że król Polski w tej formie wynagrodził husytów za przyjacielską pomoc ${ }^{53}$. Tego typu wątpliwości nie ma już jednak większość współczesnych historyków. Czesław S. Bartnik bez wahania stwierdza, że "husytów wzięto nie jako sojuszników, ale raczej jako najemników" 54 .

W 1434 r. zmarł Władysław Jagiełło. Kościół husycki był już wówczas pogodzony z soborem bazylejskim (kompaktaty $30 \mathrm{X} 1433$ ), wkrótce miał zostać zgnieciony radykalny ruch taborytów (Lipany $30 \mathrm{~V} 1434$ ), w $1435 \mathrm{r}$. stany czeskie uznały władzę królewską Luksemburczyka, który koronował się w 1436 r. na króla Czech w Pradze. Polska polityka wobec Czech również zmieniła swoje oblicze. Jan Kurnatowski zauważa, że nową kategorią, jaka pojawiła się w stosunkach z Czechami za Władysława i Kazimierza Jagiellończyków, było niemal całkowite wyeliminowanie $\mathrm{z}$ niej motywu religijnego ${ }^{55}$.

Podsumowując wątek wpływów husytyzmu w polskiej polityce zagranicznej, warto zacytować na koniec opinię Zenona Nowaka, który w Historii dyplomacji polskiej podkreśla, że polityka wobec Czech była chwiejna i niezdecydowana oraz że w żadnym wypadku nie można jej nazwać sukcesem. Autor uważa, że wręcz przeciwnie, przyniosła ona więcej strat niż korzyści, głównie z tego powodu, że „stała się podstawą do ustawicznych oskarżeń w Europie o sprzyjanie heretykom. Groziło to nie tylko komplikacjami międzynarodowymi, ale było to sprzeczne $z$ interesami państwowymi" ${ }^{56}$.

Wszelkie próby podsumowania znaczenia, jakie miał dla Polski wpływ ruchu husyckiego, zawierają zazwyczaj wątek narodowy. Nie chodzi tu jednak o impuls w rozwoju świadomości narodowej, bo tego rodzaju procesy, przyznaje sama Ewa Maleczyńska, mają znacznie starszą metrykę, sięgającą

53 J. Macek, Husyci na Pomorzu i w Wielkopolsce, Warszawa 1955, s. 45.

54 Cz. S. Bartnik, op.cit., s. 126.

55 J. Kurnatowski, Polskie kandydatury na tron czeski, Warszawa 1932, s. 33.

56 Z. Nowak, Dyplomacja polska w czasach Jadwigi i Jagietty (1383-1434), w: Historia dyplomacji polskiej, t. I, red. M. Biskup, Warszawa 1980, s. 344. 
XIV wieku i husytyzmowi nic do tego ${ }^{57}$. Roman Heck, rozważając ewolucję polskiej świadomości narodowej w średniowieczu, potwierdza opinię Ewy Maleczyńskiej, że zasadniczo sytuacja polska w porównaniu z czeską była o tyle lepsza, że nie stworzyła szczególnie podatnego gruntu pod rozwój haseł narodowościowych. Nie można bowiem mówić o wyjątkowo silnych wpływach niemczyzny wśród polskiego możnowładztwa i rycerstwa, w XV w. żywioł niemiecki w miastach zasymilował się już z miejscowym, a jeżeli osiągał gdzieś znaczniejszą przewagę, to tylko w kilku największych ośrodkach handlowych. Podobnie Kościół w XV w. funkcjonował już od dwóch stuleci na zasadach wyznaczonych przez arcybiskupa Jakuba Świnkę. Beneficja powiązane $\mathrm{z}$ obowiązkami duszpasterskimi mogły być nadawane tylko kapłanom urodzonym w Polsce i władającym biegle językiem polskim ${ }^{58}$. Wszystko to sprawiło, że husytyzm nie miał już na gruncie polskim pola do popisu i nie mógł odegrać roli decydu jącego czynnika w rozbudzaniu polskiej świadomości narodowej. Natomiast elementem, którego znaczenia nie można umniejszyć, jest wkład, jaki miał husytyzm w rozwój polskiego języka literackiego. Doniosłą rolę wpływów czeskich podkreśla Jerzy Kłoczowski, wskazując, że literatura czeska w XV w. pozostawała na zdecydowanie wyższym poziomie niż twórczość polska w analogicznym okresie. Rozkwit rodzimego piśmiennictwa w epoce renesansu zawdzięczamy, w przekonaniu Jerzego Kłoczowskiego, ewolucji, która dokonała się w XIV-XV w., a w której niebagatelną rolę odegrały także impulsy z Czech $^{59}$. Karol Hławiczka poszukiwał śladów husytyzmu w hymnologii polskiej. Udało mu się zidentyfikować kilka pieśni, w których, jego zdaniem, przetrwały tradycje husyckie. Wymienia pieśń Jezu Chryste, nasza radości, której pierwszy wiersz jest kalką z Husa Jesu Christe nostra salus. Podaje również przykład pieśni Przestrach na zte sprawy ludzkiego żywota, ciekawej o tyle, że skomponowano do niej melodię na wzór husyckiego hymnu Kdož jsu boži bojovnicy ${ }^{60}$. Wpływy narodowej ideologii husytyzmu zauważa Benedykt Zientara w zjawisku, które nazywa nacjonalizmem językowym. Śladów tego rodzaju poszukiwał między innymi w memoriale Jana Ostroroga Monumentum pro reipublicae ordina-

57 E. Maleczyńska, Ruch husycki..., s. 528; podobnie: idem, Ze studiów nad hastami narodowościowymi w źródłach doby husyckiej, "Przegląd Historyczny” 43 (1952), s. 77.

58 R. Heck, Uwagi o rozwoju polskiej i czeskiej świadomości narodowej w średniowieczu, w: Studia nad rozwojem narodowościowym Polaków, Czechów i Stowaków, red. R. Heck, Wrocław 1976, s. 9-11.

59 J. Kłoczowski, op.cit., s. 308; T. Michałowska, op.cit., s. 329.

60 K. Hławiczka, Ślady husytyzmu w hymnologii polskiej, „Jednota” 7-8 (1971), s. 14. 
tionae. Wymienia postulaty Ostroroga przypominające w swej treści hasła husyckie, np.: obowiązek głoszenia w polskich kościołach kazań po polsku ${ }^{61}$. Stosunkowo najbardziej krytycznie wypowiada się o wpływach husyckich na język polski S. Kolbuszewski. Uważa on, że krążąca w Polsce literatura husycka nie przyczyniła się do wzbogacenia polskiej sztuki literackiej w XV w., nie wyłączając Gałki Pieśni o Wiklefie. Wpływy czeskie ogranicza do roli pomocnika językowego, natomiast zasadniczo odmawia im roli impulsu twórczego. Na dowód przypomina, że przeważająca część utworów w języku polskim powstała zupełnie niezależnie od literatury czeskiej i bez jej udziału ${ }^{62}$.

Z powyższych rozważań może chyba płynąć wniosek, że nie należy traktować husytyzmu polskiego jako czegoś więcej niż epizodu w polskich dziejach. Niezaprzeczalnie pozytywne znaczenie husytyzmu w rozwoju polskiej kultury językowej, pewien udział w wyznaczaniu kierunków polskiej polityki zagranicznej, odgrywanie roli w wewnętrznych rozgrywkach politycznych czy wreszcie dostarczenie impulsu do pewnego ożywienia życia religijnego nie wyznaczają jednak ruchowi husyckiemu poczesnego miejsca wśród polskich czynników historiotwórczych. Należy chyba zgodzić się z opinią, że polski husytyzm był jedynie słabym refleksem bogatego w treści ideowe i potężnego pod względem oddziaływania społecznego ruchu husyckiego w Czechach. W Polsce istniał dopóty, dopóki istniała dla niego dobra koniunktura. Zniknął, gdy przestał być wygodnym instrumentem w walce politycznej z Kościołem i oligarchią magnacką ${ }^{63}$.

61 B. Zientara, op.cit., s. 202. s. 68 .

62 S. Kolbuszewski, Polska a Czechy. Zarys zagadnień kulturalnych, Poznań 1939, 63 P. Kras, op.cit., s. 317. 